Piotr Cieślik, Agata Bielawska-Drózd, Patrycja Głowacka, Dorota Żakowska Lidia Mizak, Grzegorz Graniak and Romuald Gryko

\title{
5. METHODS OF BIOLOGICAL SAMPLES FIELD ANALYSIS
}

\subsection{Introduction}

Biological agents that can be used as biowarfare agents (BWA) are the most dangerous threats, and can have an influence on large numbers of both humans and animals. In terms of health protection, as well as prevention of BWA attacks, rapid diagnostics are the most important step in the case of sudden suspicious situations. According to AEP-66 NATO protocols, three detection levels are required: Provisional - one of the following criteria must be met (immunological assays, detection of nucleic acids, culturing); Confirmed - two of the listed criteria must be applied (immunological assay, molecular method, culturing), and Unambiguous - all of the listed criteria must be applied (immunological assay, molecular method, culturing and animal model testing, if possible/necessary). Two of the levels (Provisional and Confirmed) can be determined in the field by a sampling team at the Provisional stage, or at a mobile laboratory (Confirmed), if available at the time of the field research. Immunoassay mainly includes rapid immunochromatographic tests that return results in 10-15 min. These tests do not require specialized equipment and skilled personnel. However, the major limitation is the sensitivity of the tests, as even negative results do not exclude the presence of the biological agents tested for. Samples must then be transferred to a mobile laboratory or stationary reference laboratory for further analyses. Molecular techniques are one of the most commonly in detection of biowarfare agents, in labs and in the field. Several instruments and reagents allow for rapid, accurate and specific identification of biological agents using Polymerase Chain Reaction method (PCR). Nowadays, classic PCR is not routinely used and has been replaced with real-time PCR. This method is more sensitive and need the short time for experiment, the fact that they can be run in multiplex format, and their ease of use after just a short training period. Finally, most of the immunological tests dedicated to environmental screening are not subject to in vitro diagnostics, including clinical samples. 


\subsection{Immunoassays (IA)}

Immunoassays methods are based on detection of antibodies or antigens which may be found in number of different samples, e.g. clinical samples (animal and human serum samples), environmental samples such as water, soil, powder, swipes from the abiotic surfaces or carcasses. IA methods allow testing various of them on site in the field conditions as well as in the mobile laboratory. Most commonly used tests are the rapid immunochromatographic assays and enzymelinked immunosorbent assay (ELISA). In case of rapid chromatographic test they are designed for field detection and are prepared in vacuum-foiled bags with appropriate sample buffers, consumables and practical instruction how to prepare samples. Large number of test may be adopted in case of rapid field detection of biological agents concern biowarfare (Table 1). The results are available within after about $10-15$ minutes.

ELISA is another immunological method that allows detection of antibodies antigens. It can be done only in laboratory conditions, also in the field laboratory which may be equipped with ELISA readers and others instruments required for sample preparation workflow. Number of samples of different origin can be tested with ELISA: animal and serum samples, environmental samples (soil, water, powders, swipes). However this method characterizes with moderate sensitivity and specificity, especially in case of environmental samples where chemical inhibitors may be found, it is routinely used in samples diagnostic scheme at the Confirmed stage.

\subsubsection{Rapid Immunochromatographic Assay}

Rapid immunochromatographic tests, or SMART (Sensitive Membrane Antigen Rapid Test) belong to modern and rapid detection technologies for biological agents. This technique applies mono-, or polyclonal antibodies tagged with colloidal gold immobilized on a nitrocellulose membrane. It is a rapid and costeffective preliminary detection and identification method used routinely in the field.

In the SMART method, two types of antibodies directed against the antigen are used: one is immobilized on nitrocellulose membrane, while the other is labelled with colloidal gold and penetrates through the test surface. If the sample is positive antigen binds to the colloidal gold, hence to the appropriate antibodies. This complex is moves along the membrane until an immobilized on the membrane antibodies. This effect is visible as a line. If there are not antigens in sample, colloidal gold labelled antibodies don't bind to the antigen and antiantigen antibody. Control line is visible when colloidal gold labelled antibody connects with control antibodies.

These tests allow biological weapons agents factors detection for example: anthrax, ricin toxin, botulinum toxin, plague, or SEB (Staphylococcal enterotoxin B) and others biological factors (Table 1). 


\section{POSITIVE}
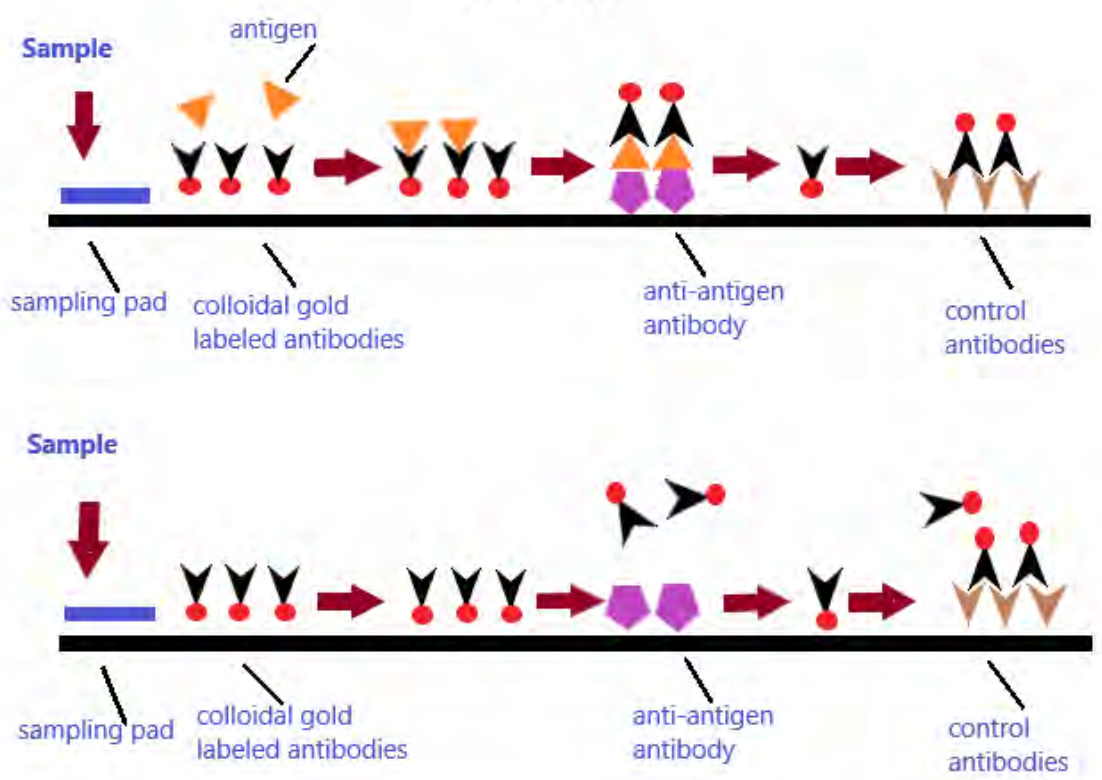

NEGATIVE

Figure 1. Basic principles of SMART immunoassay tests (Author: Patrycja Głowacka)

Table 1. Commercially available immunoassay tests

\begin{tabular}{|l|l|l|}
\hline \multicolumn{1}{|c|}{ Biological agent } & \multicolumn{1}{c|}{ Lateral flow assays } \\
\hline \multicolumn{1}{|c|}{ Category A } & \multicolumn{1}{|c|}{ Producer } & \multicolumn{1}{c|}{ Test name } \\
\hline Anthrax & New Horizons Diagnostic & SMART II \\
(Bacillus anthracis) & ADVNT Biotechnologies & BADD \\
& BIOFIRE & Biothreat Panel \\
& Response Biomedical & RAMP \\
& Tetracore & BTA \\
& Alexter Technologies & Biodetect Tests and RAID \\
& Environix & ENVI \\
\hline
\end{tabular}


Table 1. cont.

\begin{tabular}{|c|c|c|}
\hline Biological agent & \multicolumn{2}{|c|}{ Lateral flow assays } \\
\hline $\begin{array}{l}\text { Botulism } \\
\text { (Clostridium botulinum } \\
\text { toxin) }\end{array}$ & $\begin{array}{l}\text { ADVNT Biotechnologies } \\
\text { Tetracore } \\
\text { Response Biomedical } \\
\text { Alexter Technologies } \\
\text { Environix }\end{array}$ & $\begin{array}{l}\text { BADD } \\
\text { BTA } \\
\text { RAMP } \\
\text { Biodetect Tests and RAID } \\
\text { ENVI }\end{array}$ \\
\hline $\begin{array}{l}\text { Plague } \\
\text { (Yersinia pestis) }\end{array}$ & $\begin{array}{l}\text { ADVNT Biotechnologies } \\
\text { Tetracore } \\
\text { BIOFIRE } \\
\text { Alexter Technologies } \\
\text { Environix }\end{array}$ & $\begin{array}{l}\text { BADD } \\
\text { BTA } \\
\text { Biothreat Panel } \\
\text { Biodetect Tests and RAID } \\
\text { ENVI }\end{array}$ \\
\hline $\begin{array}{l}\text { Smallpox } \\
\text { (Variola major) }\end{array}$ & $\begin{array}{l}\text { Response Biomedical } \\
\text { Alexter Technologies }\end{array}$ & $\begin{array}{l}\text { RAMP } \\
\text { RAID }\end{array}$ \\
\hline $\begin{array}{l}\text { Tularemia } \\
\text { (Francisella tularensis) }\end{array}$ & $\begin{array}{l}\text { New Horizons Diagnostic } \\
\text { ADVNT Biotechnologies } \\
\text { BIOFIRE } \\
\text { Tetracore } \\
\text { Alexter Technologies } \\
\text { Environix }\end{array}$ & $\begin{array}{l}\text { SMART II } \\
\text { BADD } \\
\text { Biothreat Panel } \\
\text { BTA } \\
\text { Biodetect Tests and RAID } \\
\text { ENVI }\end{array}$ \\
\hline Ebola virus & BIOFIRE & Biothreat Panel \\
\hline Marburg virus & BIOFIRE & Biothreat Panel \\
\hline \multicolumn{3}{|l|}{ Category B } \\
\hline $\begin{array}{l}\text { Brucellosis } \\
\text { (Brucella species) }\end{array}$ & $\begin{array}{l}\text { ADVNT Biotechnologies } \\
\text { Tetracore } \\
\text { BIOFIRE } \\
\text { Genomix Biotech } \\
\text { Alexter Technologies }\end{array}$ & $\begin{array}{l}\text { BADD } \\
\text { BTA } \\
\text { Biothreat Panel (B. meli- } \\
\text { tensis) } \\
\text { Brucella Antibody Test Kit } \\
\text { Biodetect Tests and RAID } \\
\end{array}$ \\
\hline $\begin{array}{l}\text { Epsilon toxin of Clostridi- } \\
\text { um perfringens }\end{array}$ & Thermo Fisher Scientific & $\begin{array}{l}\text { Epsilon Toxin Rapid Test } \\
\text { Kit }\end{array}$ \\
\hline Salmonella & New Horizons Diagnostic & SMART II \\
\hline E. coli $\mathrm{O} 157: \mathrm{H} 7$ & New Horizons Diagnostic & SMART II \\
\hline Shigella & Meridian Healthcare & $\begin{array}{l}\text { Rapid-VIDITEST Shigella } \\
\text { spp., S. dysenteriae }\end{array}$ \\
\hline
\end{tabular}




\begin{tabular}{|c|c|c|}
\hline Biological agent & \multicolumn{2}{|c|}{ Lateral flow assays } \\
\hline $\begin{array}{l}\text { Glanders } \\
\text { (Burkholderia maleli) }\end{array}$ & BIOFIRE & Biothreat Panel \\
\hline $\begin{array}{l}\text { Psittacosis } \\
\text { (Chlamydia psittaci) }\end{array}$ & Bioplus & Chlamydia antigen \\
\hline $\begin{array}{l}\text { Q fever } \\
\text { (Coxiella burnetii) }\end{array}$ & BIOFIRE & Biothreat Panel \\
\hline Ricin toxin & $\begin{array}{l}\text { ADVNT Biotechnologies } \\
\text { Response Biomedical } \\
\text { Alexter Technologies } \\
\text { Environix }\end{array}$ & $\begin{array}{l}\text { BADD } \\
\text { RAMP } \\
\text { Biodetect Tests and RAID } \\
\text { ENVI }\end{array}$ \\
\hline $\begin{array}{l}\text { Staphylococcal enterotoxin } \\
\text { B }\end{array}$ & $\begin{array}{l}\text { New Horizons Diagnostic } \\
\text { ADVNT Biotechnologies } \\
\text { Environix }\end{array}$ & $\begin{array}{l}\text { SMART II } \\
\text { BADD } \\
\text { ENVI }\end{array}$ \\
\hline $\begin{array}{l}\text { Typhus fever } \\
\text { (Rickettsia prowazekii) }\end{array}$ & ImmuneMed & Murine Typhus Rapid \\
\hline Vibrio cholerae & New Horizons Diagnostic & SMART II \\
\hline Cryptosporidium parvum & Thermo Fisher Scientific & $\begin{array}{l}\text { Cryptosporidium parvum } \\
\text { Rapid Test }\end{array}$ \\
\hline
\end{tabular}

One of the most important disadvantage is the range of detection limit between $1.5 \times 10^{4}$ to $8.3 \times 10^{8}$ spores $/ \mathrm{ml}$ for B. anthracis, or for other biological agents about $1.0 \times 10^{5} \mathrm{CFU} / \mathrm{ml}$. For bacteriological toxins limit detection is about $10-30 \mathrm{ng} / \mathrm{ml}$, but for ricin toxin: $5 \mathrm{ng} / \mathrm{ml}$ in ENVI test. In relation to above limitations, negative results of IA tests should not be considered as 'negative' and samples must be forwarded to stationary reference laboratory, or mobile laboratory for confirmatory tests.

\subsubsection{ELISA}

Enzyme-linked immunosorbent assay as a EIA (Enzyme Immunoassay) is adopted for detection the presence either antibodies produced in response to infection, or antigens from the infecting agents in examined samples.

In the ELISA assay, the targeted antigen is immobilized to the polystyrene plate directly by adsorption, or indirectly using the capture antibody attached to the plate. The direct and indirect antigen detection is carried out relatively using the enzyme-conjugates primary antibody or enzyme-conjugated secondary antibody with unlabelled primary antibody. 


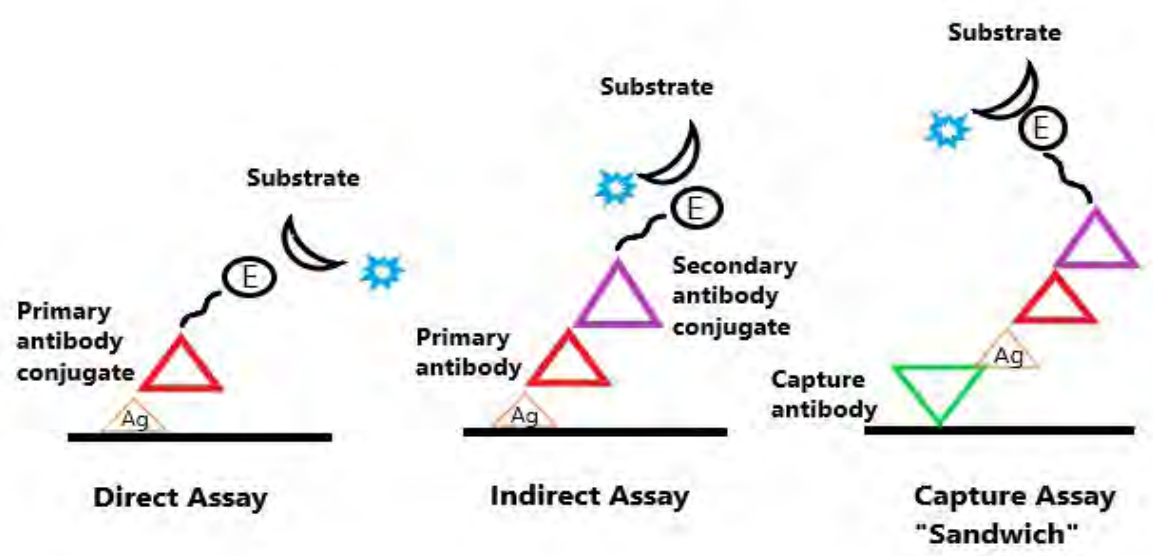

Figure 2. The ELISA reaction (Author: Patrycja Głowacka)

For biothreat detection the directed ELISA method to antigens is implemented. In case of particular antigen detection presented in environmental samples (suspension of solid material e.g. powder, soil or liquids or swipes) the specific antibodies are used. These antibodies may be adopted for reaction with different protein epitopes. The unknown antigen should be affixed to the surface of polystyrene microwells, and the binding of antigen and specific antibody should be revealed by applying the antibody covalently linked to the enzyme. Between each step for removing the residual components, not specifically bounded antigens, or antibodies, the washing with detergent solution should be applied. In final step the enzyme converts the special chemical substrate to visible signal which is detected spectrophotometrically. The intense of coloured signal indicates the quantity of antigen in examined samples.

ELISA can be used as convenient tool for screening large numbers of smallvolume examined samples. The use of a monoclonal antibody in immunoassay results in high specificity of the reaction and it has low level background. However, the polyclonal antibodies can increase the range of the assay to detect multiple isolates belonging to different species of bacteria, virus, or fungi.

For the detection of biological biothreat agents (and simulants e. g. Bacillus globigii) in environmental samples BioThreat Alert ${ }^{\circledast}$ ELISA Kits are available (Tetracore). Additional, this method is preferred for complex sample matrices belonging to category A (according to CDC) bioterrorism agents (Bacillus anthracis, Clostridium botulinum toxin, Yersinia pestis, Francisella tularensis), and category B (Brucella spp., Burkholderia spp, Vibrio cholerae, Staphylococcal Enterotoxins (SEB), Ricin toxin from Ricinus communitis and abrin toxin from Abrus precatorius) (http://tetracore.com/elisa-kits/index.html). All of the tests 
are recommended for samples with complexed matrices. ELISA preparation workflow requires specific instruments, including ELISA readers and washers for reaction preparation and results data analysis what makes this method available only in the laboratory conditions (stationary or mobile).

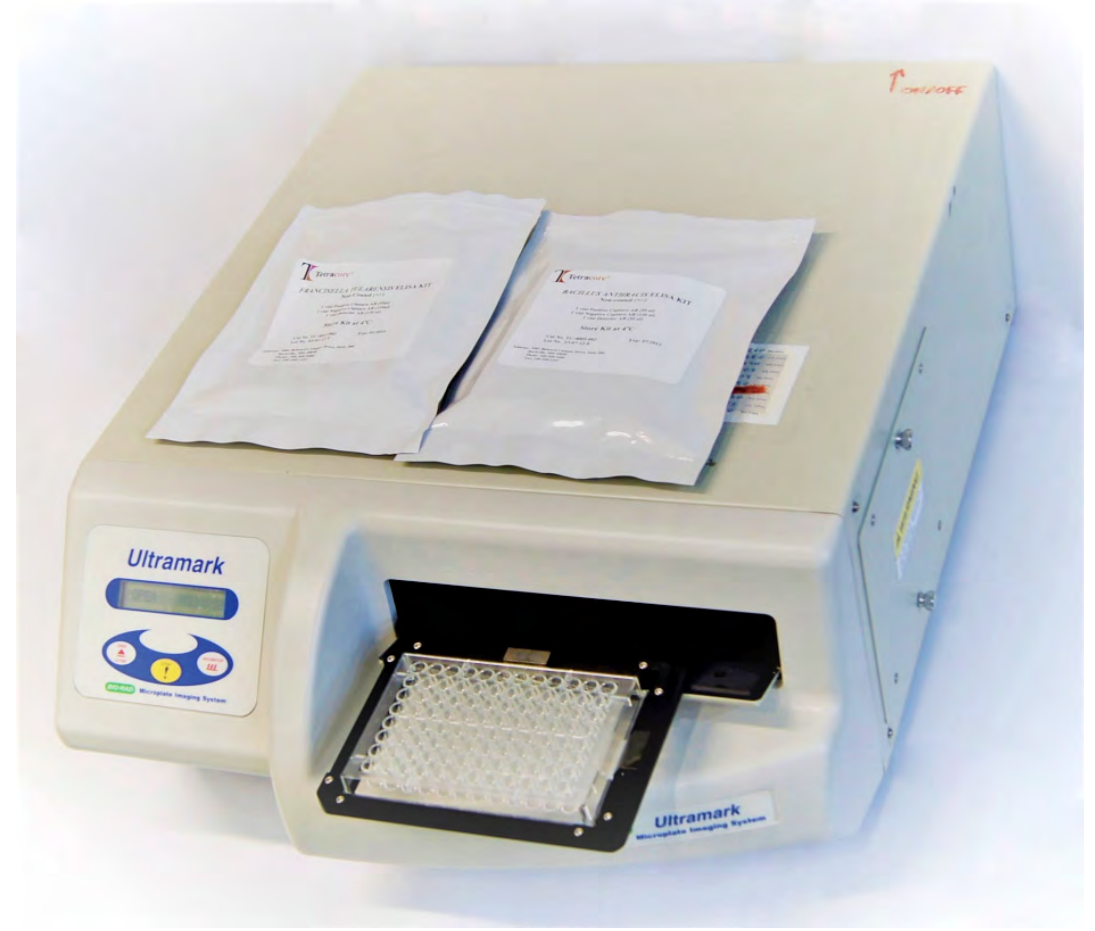

Figure 3. The Tetracore system (BTICC)

\section{pBDi Detector (Bruker)}

ELISA for detection of biothreats can be automated. Portable instrument that is designed to use directly on-site for detection and identification of biological agents and it is pBDi Detector (Bruker). Its capabilities allow rapid as well as specific detection of biological warfare agents and toxins (Bacillus anthracis, Yersinia pestis, Francisella tularensis, Brucella melitensis, Burkholderia mallei, Orthopox viruses (Smallpox), botulinum toxin A, B, C, D, E, F, Staphylococcal enterotoxin $A$ and $B$, ricin, abrin) with easy-to-use workflow. One of the advantage is it can be operated by non-skilled personnel and may be adopted in hot zone (www.bruker.com). The specifications of this detector can be found on www. bruker.com. 


\subsubsection{Immunofluorescence (IFA)}

Immunofluorescence (IFA) - is a laboratory technique to identify the presence of antibodies bound to specific antigens with use fluorescent dyes. There are two types of IFA: direct and indirect. In direct IFA only primary antibody labelled with appropriate fluorescent dye against targeted antigen is present. In case of indirect method, two classes of antibodies are used - primary and secondary, where secondary antibody (labelled with fluorescent dye) attach to primary antibody. Results can be seen only when using fluorescent microscope what makes this method available only in laboratory and require skilled personnel. The most commonly use dye include fluorescein isothiocyanate (FITC) which after excitation emits green and tetramethylorodine isothiocyanate (TRITC), which after excitation emits a red colour.

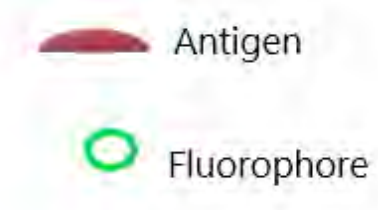

DIRECT

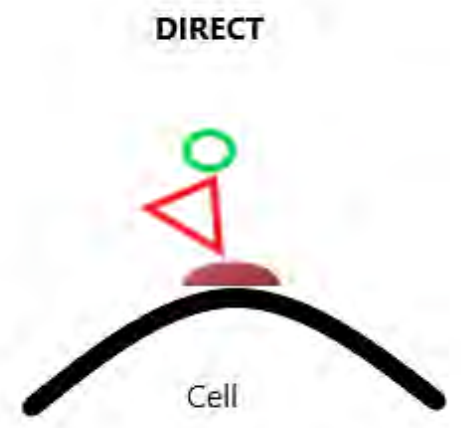

Figure 4. Direct and Indirect Immunofluorescence (IFA) testing (Author: Patrycja Głowacka)

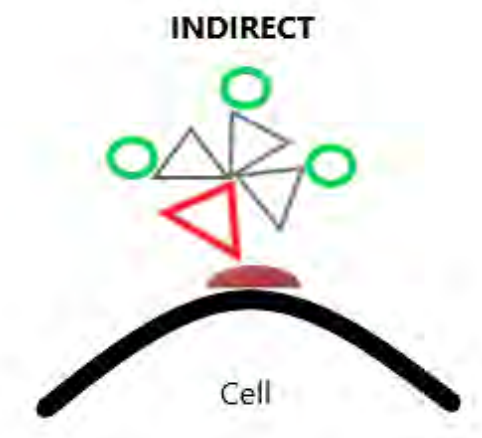

INDIRECT
Primary Antibody

Secondary Antibody

In an indirect IFA, human antibodies associated with the microorganism are detected by fluorescein-labelled anti-human antibodies. In direct IFA the antigen reacts with the dye labelled antibody to give the antigen-antibody complex.

Finally, there are no IFA tests for biothreat agents in the case of detection of environmental samples. Number of test are dedicated for diagnostics of clinical samples. 


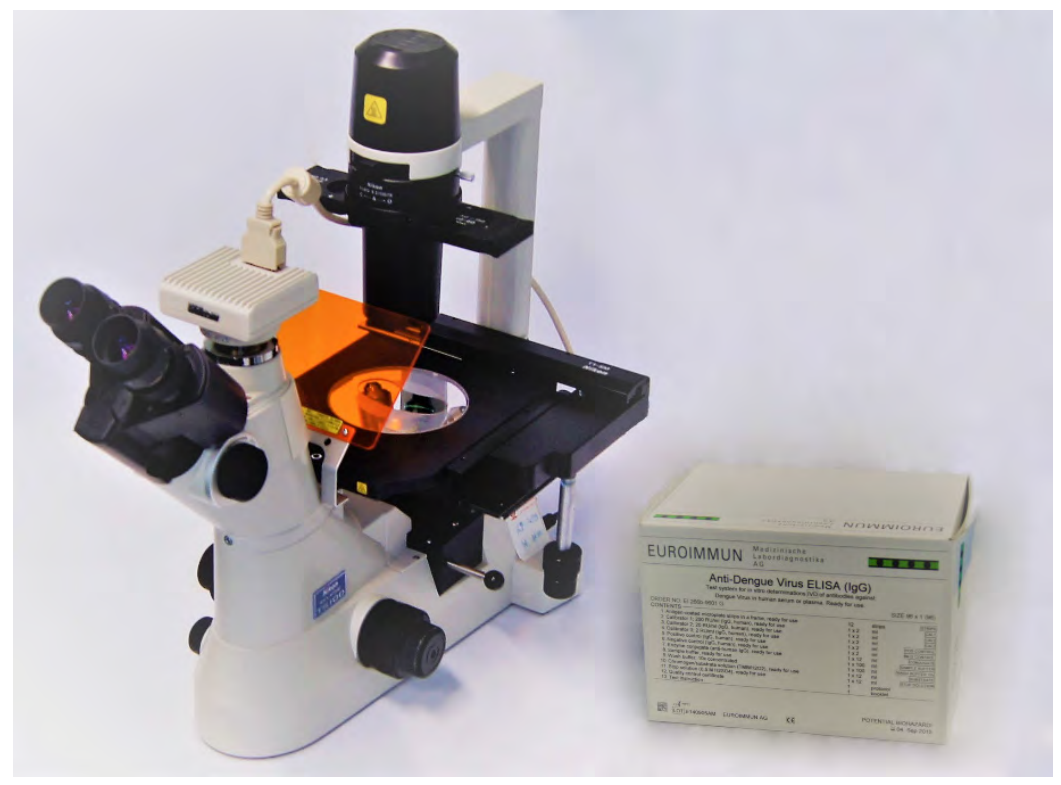

Figure 5. Fluorescent microscopy (BTICC)

\subsection{Molecular methods}

For the identification of BW agents the several genetic based assay methods are available. The methods are based on the molecular taxonomy of bacteria using the analysis of genetic sequences of subunits $16 \mathrm{~S}$ or $23 \mathrm{~S}$ rRNA. The nucleic acid hybridization is based on the DNA or RNA complementary to synthesized unique sequence labelled with enzyme or fluorochrome or radioactive compounds. The techniques dedicated to DNA or RNA detection are called Sothern blot and Northern blot, respectively. However, they are not routinely used because of the time of experiments and highly skilled laboratory personnel.

The most common method for detection and identification of biological agents is PCR and its modification real-time PCR. These methods allow detection a DNA from a single bacterial cell or RNA from viruses, thanks to modification called Reverse Transcriptase real-time PCR (RT real-time PCR). Real-time PCR method involves using a molecular probe labelled with fluorescent dye and quencher (this modification is also known as TaqMan ${ }^{\otimes}$ probe). Positive results are revealed as a fluorescemce curve curves. This method does not require agarose gel electrophoresis. However, it requires highly skilled personnel and basic knowledge about molecular biology. Despite this inconvenience, real-time PCR has become a standard method in most laboratories around the world. Other 
probes like: HybProbes ${ }^{\oplus}$, molecular beacons and Skorpion ${ }^{\circledast}$ probes can also be used however they are expensive and designing process is very difficult and time consuming are routinely used for scientific research.

Some modifications of real-time PCRidentification techniques are dedicated to military use and represent closed versions of the instruments (http://www. biofiredx.com).

The development of DNA amplification makes possible to extract the thermostable DNA polymerase from Thermus aquaticus bacterium (Taq polymerase). That microorganism lives in hot sources at $50-80^{\circ} \mathrm{C}$ of Yellowstone Park in USA. PCR technique was developed by Kary Mullis in 1983 (in 1993 received Noble Price for his discovery). Quantitative polymerase chain reaction (qPCR) use the fluorescent dyes and serves as technique that enable monitoring of PCR amplicons with the fluorescent dyes. Due to this the procedure the analysis is relevant, less-labour intensive, accurate and eliminates electrophoresis gel process for PCR products' detection. The method measures the quantity DNA in real - time process.

Reverse transcriptase PCR (RT-PCR) is a method of converted RNA molecules into complementary DNA (cDNA). Reverse transcriptase is an enzyme used for this purpose. Newly synthesized cDNA is amplify in standard PCR. Techniques are useful to amplify viral RNA. This method can used in classic or real-time PCR format as well, but it takes more time because of. The advantage is a single tube reaction format, wherea template the RNA is added, not necessary cDNA. It is convenient and saving time for other analysis.

Last decade has showed a rapid development of other real-time PCR methods. One of them is Loop mediated isothermal amplification PCR (LAMP PCR). Contrary to standard PCR and real-time PCR methods that must be conducted on thermocyclers with use of temperature range (between $50-95^{\circ} \mathrm{C}$ ), LAMP PCR is performed at constant temperature and does not required thermocyclers. It can also be combined with reverse transcriptase enzyme for detection viral genetic material (RNA). In the LAMP-PCR method target nucleic sequence is detected using two or three pairs of primers where molecular probes or DNA incorporating dyes may be added as an reaction indicators. In case of SYBR Green dye (incorporating dye), UV light emitted lamp is sufficient for LAMP results visualization. Because of simple reaction format, rapid result (up to 1 hour), high specificity and reproducibility LAMP PCR has become an interesting molecular tool for detection of number biological, including biowarfare agents.

\subsubsection{Real-time PCR SYBR Green}

The most common real-time PCR technique is based on the non-specific fluorescent dyes that intercalate with double stranded DNA. The PCR products' detection is monitored by measuring the increase in fluorescence 
throughout the cycle. The disadvantage of SYBR Green PCR is detection of all double-stranded DNA (not only targeted DNA). It is necessary to carefully optimize the reaction and additional determine the melting curve analysis of PCR products.

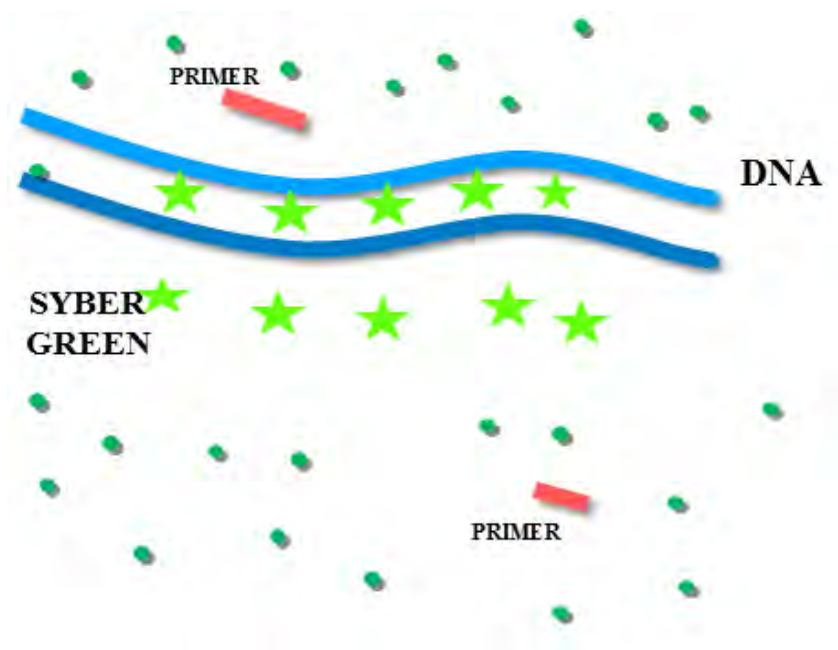

Figure 6. Real-time PCR using SYBR Green (Author: Agata Bielawska-Drózd)

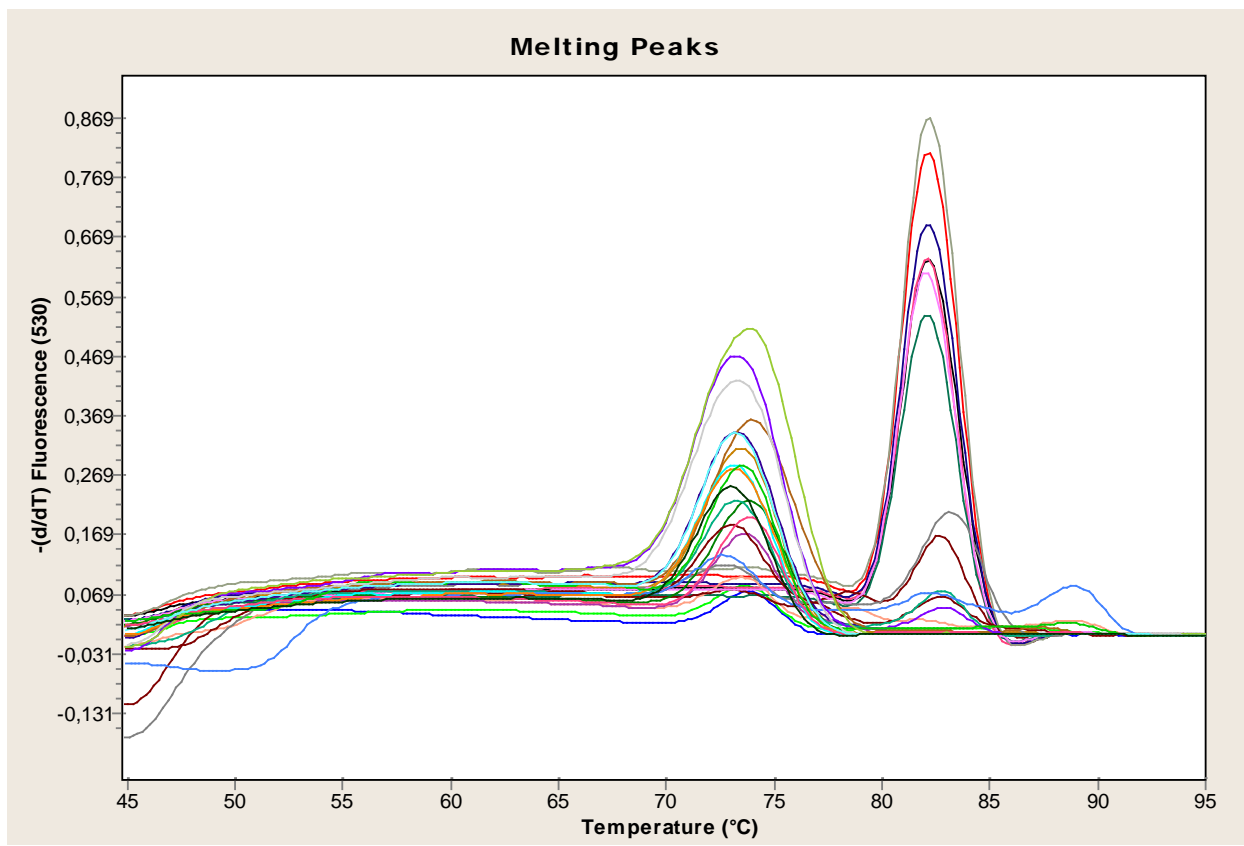

Figure 7. Melting curve analysis for targeted PCR products using SYBR Green 


\subsubsection{HybProbe real-time PCR}

The specificity and sensitivity of PCR reaction may be utilized using by fluorescent-labelled target-specific probes. Fluorescence is contingent on the hybridization of both oligonucleotides so fluorescence measuring is performed at the annealing step of the PCR cycle.
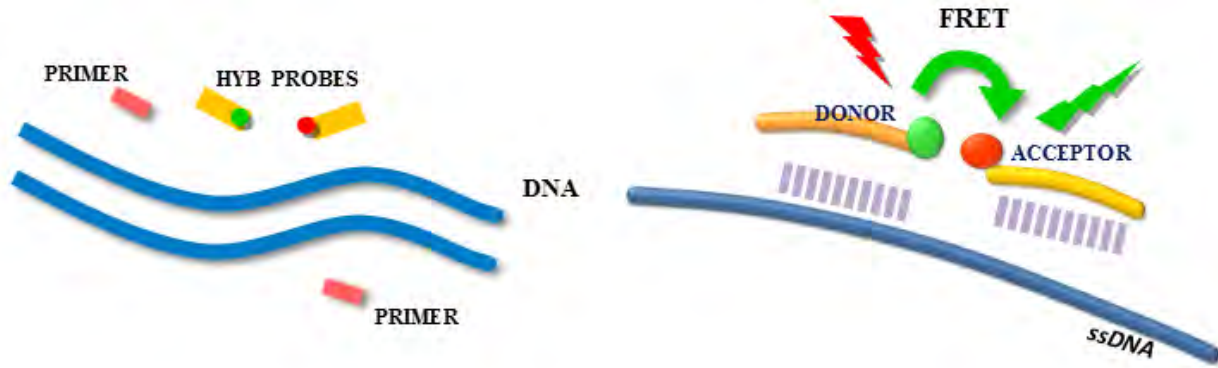

Figure 8. HybProbe real-time PCR (Author: Agata Bielawska-Drózd)

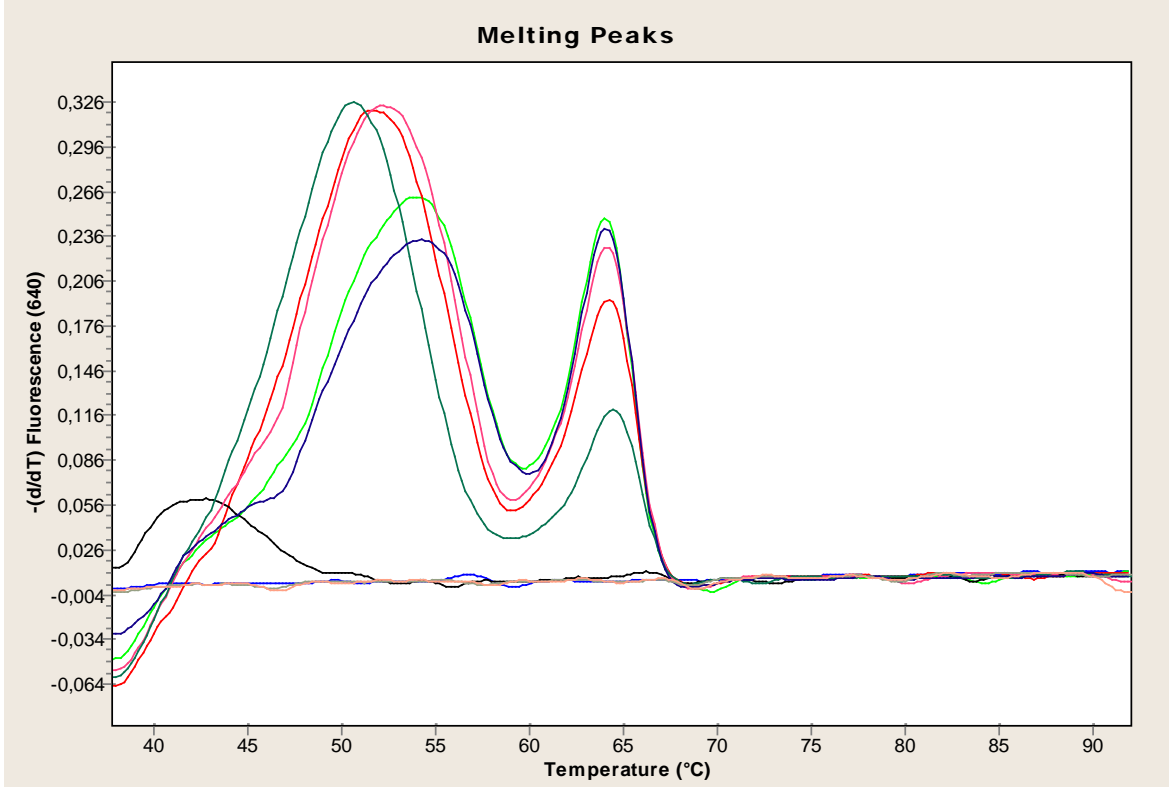

Figure 9. Results of real-time PCR using hybridization probes

The activity of hybridization probes is based on FRET (Fluorescence Resonance Energy Transfer) - the interaction between two dyes molecular 
probes in close proximity causes the transfer of energy from donor to acceptor. The acceptor fluorophore emits longer wavelength which may be measured in specific channels.

\subsubsection{TaqMan real-time $P C R$}

TaqMan real-time PCR uses TaqMan probes with 5'nuclease activity. They are short oligonucleotides of a double - labelled fluorophores. The reporter dye (e.g. FAM, HEX, ROX) and quencher dye (e.g. TAMRA, DABCYL, BHQ) are attached to the 5' and 3' ends, relatively. The 5'nuclease PCR enables to produce specific PCR products by cleavage of a double-fluorogenic labelled probes using Taq polymerase activity.

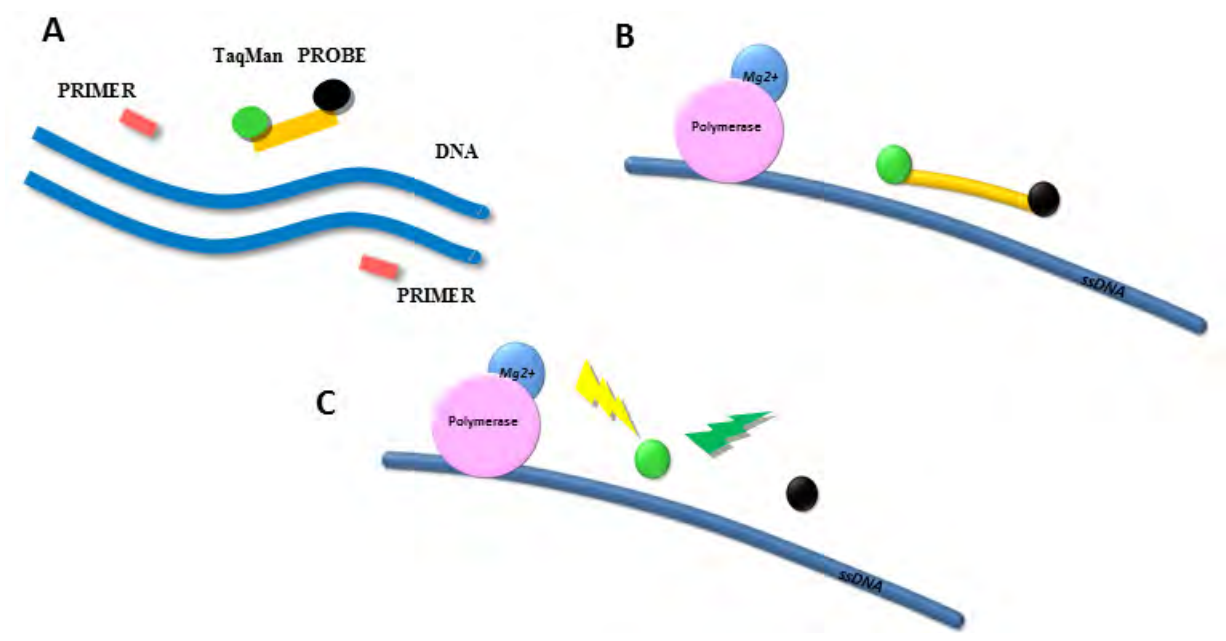

Figure 10. TaqMan real-time PCR (Authors: Agata Bielawska-Drózd, Piotr Cieślik)

The hydrolysing probes in the TaqMan method reveal the quenching of the reporter fluorescence. During hybridization to the target PCR product the probe is cleaved by the 5'-3' nuclease activity of Taq DNA polymerase. In the figure above, A is the composition of real-time PCR reaction, $B$ is the probe bind complementary to single-strand DNA (ssDNA), and $\mathrm{C}$ is the released reporter dye emits specific wavelength.

\subsubsection{Available tests and instruments}

\section{CFX96 instrument (BioRad)}

Tube Multiplex Real-Time PCR for detection of pathogen genes by TaqMan ${ }^{\circledR}$ technology. There is a wide range of variety of PCR platforms to identify biowarfare agents (viruses, bacteria). Multiplex tests are able to detecting up to 
four pathogens in one tube, and up to 33 in a single patient sample. E.coliverotoxin, Coxiella burnetii, Brucella spp., Burkholderia mallei/pseudomallei, MERS-CoV, Dengue virus, West Nile Virus, Yellow fever virus, Ebola virus, CCHFV (Crimean Congo haemorrhagic fever virus), Zika virus, Hanta virus, Chikungunya virus (http://www.labgene.ch). CFX96 instrument is only for laboratory use (also in the mobile laboratory).

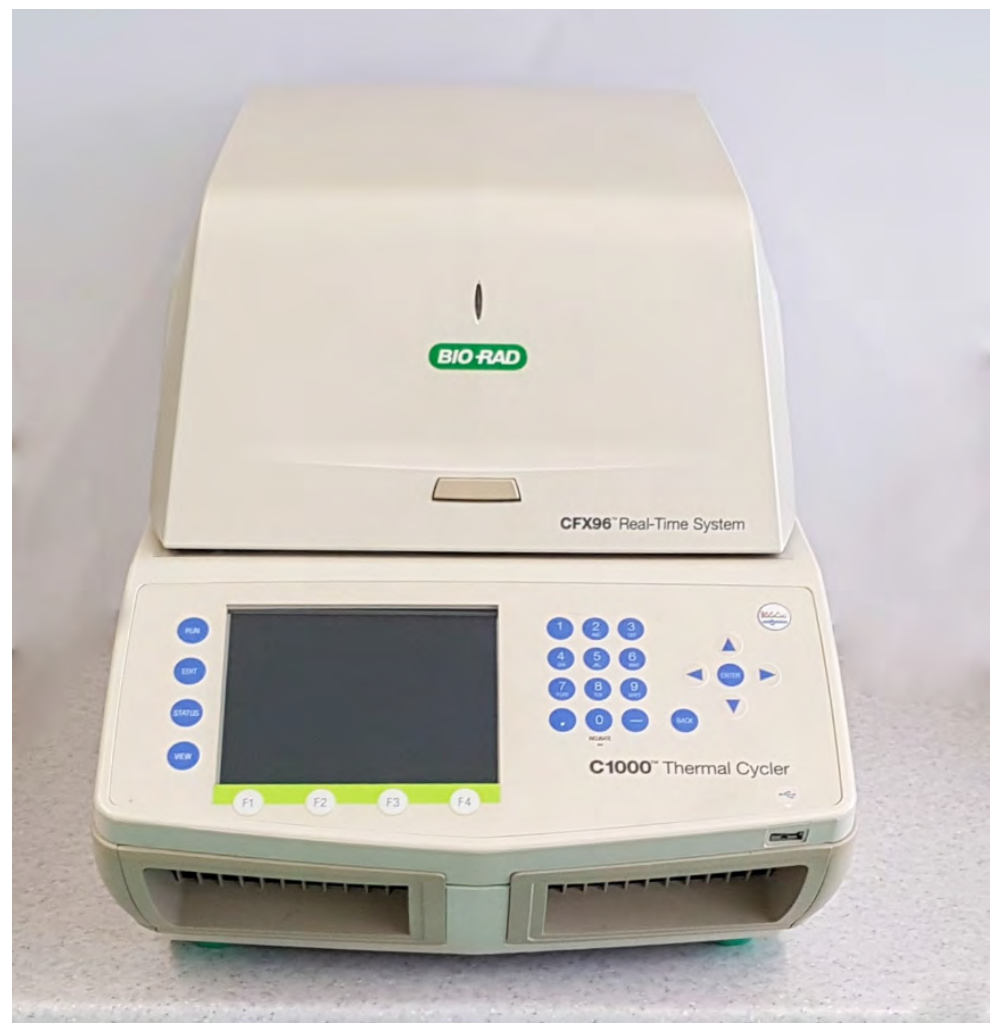

Figure 11. CFX96 Real-time system

\section{LightCycler (Roche)}

Roche molecular offers the multiplex PCR kits with TaqMan PCR for various bacterial and viral agents: set for E. coli (VTEC), Vibrio (seeds PCR) rods; cholera bacteriological examination of feces for detection Vibrio cholerae and Set LightMix Kit Dengue Virus (Types 1-4), LightMix Kit Yellow fever, TaqScreen West Nile Virus test and COBAS West Nile Virus, and LightMix ${ }^{\circledast}$ Zika rRT-PCR tests. Tests for biological agents that may cause haemorrhagic fever are also available. Instrument software allows design custom-made sets of primers and probes in 
case of interested research area. The military upgrade of LightCycler instrument, R.A.P.I.D LightCycler (BioFire), is a portable tool, that is dedicated for mobile laboratories. The range of biological agents detection covering: BioThreat Screening Kit Tests for detection B. anthracis, F. tularensis, Y. pestis, pathogen Test KitTests for: Listeria monocytogenes, E. coli O157, Salmonella spp., Campylobacter spp., Brucella spp. Other biological factors can also be detected: Cryptosporidium, variola (Small Pox), ricin, Avian Influenza H5 subtype, avian Influenza H5 Subtype, influenza A.

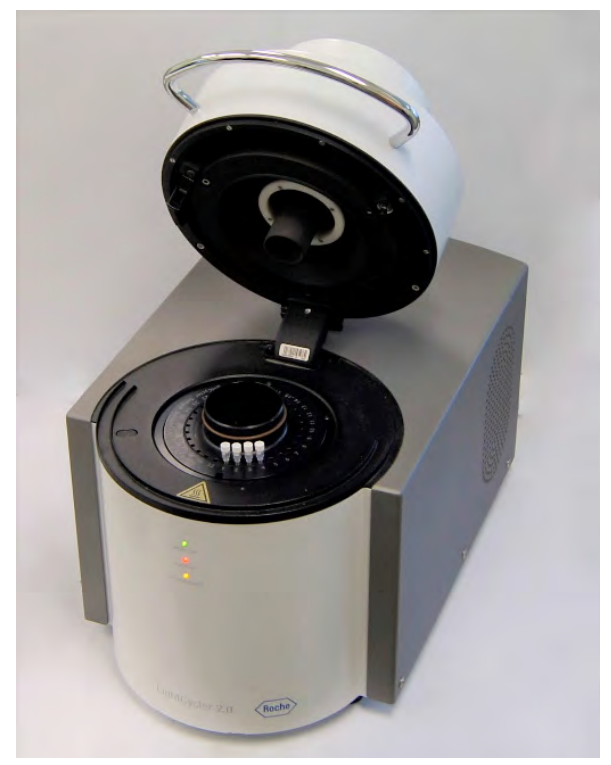

Figure 12. Light Cycler 2.0 detection system (BTICC)

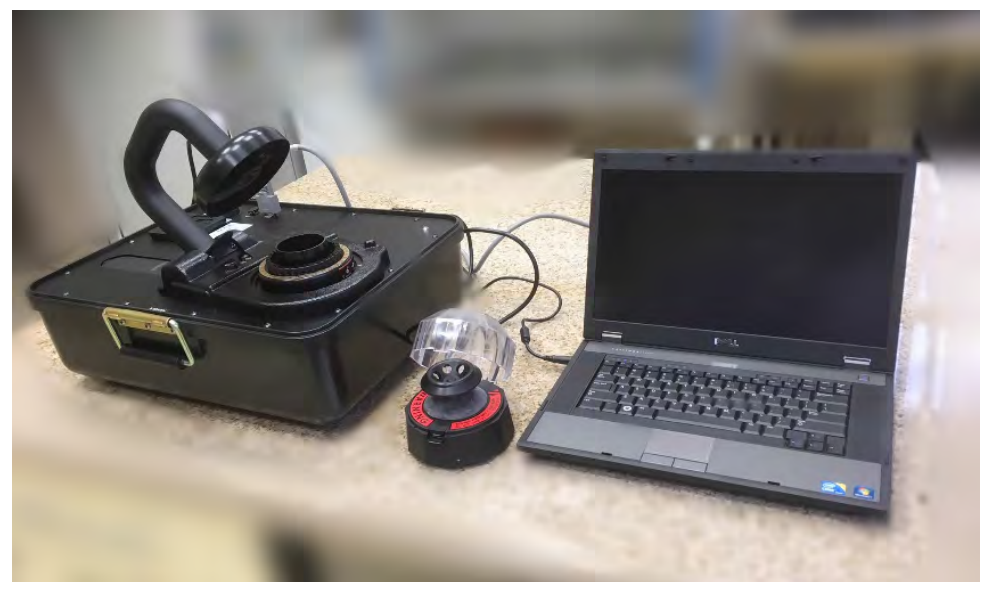

Figure 13. R.A.P.I.D LightCycler detection system 


\section{RAZOR EX BioDetection System (BioFire)}

The system enables to detect and identify biological agents in field use. The application of BioFire's patented pouch system (integrated freeze-dried reagents in special cartridges) increase reliability DNA based results. That system is convenient for the most common biothreats. This instrument because of small size and possessing own power supply (battery) can be taken directly on field or be used in the laboratory. On the producers website, instruction movie about sample processing and instrument preparation steps is available (www.biofiredx.com).

The Biothreat screening kit includes assays for: B. anthracis, F. tularensis, $Y$. pestis, Brucella species. For training on the R.A.P.I.D. instruments, kits for many different pathogens are available (Listeria monocytogenes, E. coli O157, Salmonella species, Campylobacter spp., Clostridium botulinum type A, Cryptosporidium sp., Variola virus or ricin toxin).

\section{FilmArray (BioFire)}

The Film Array BioThreat offers the BioThreat panel of 16 threat pathogens which may be detected in environmental samples within an hour, including samples genetic material extraction. The panel includes: Bacillus anthracis, (detects 3 genetic targets - chromosomal, pXO1 and pXO2), Brucella melitensis, (detects 2 genetic targets), Burkholderia, (detects 2 genetic targets), Clostridium botulinum, Coxiella burnetii, (detects 2 genetic targets), Ebola virus (Zaire), EEE virus, F. tularensis, (detects 2 genetic targets), Marburg virus, (detects 2 genetic targets), Ricinus communis, Rickettsia prowazekii, (detects 2 genetic targets), Variola virus, VEE virus, (detects 2 genetic targets), Yersinia pestis, Orthopoxvirus (detects 2 genetic targets). The FilmArray system is also integrated with freezedried reagents in special vacuum-sealed cartridges.

FilmArray is a fully automatic instrument with genetic material extraction as a part of the real-time PCR process. Sample loaded into the pouch is transferred in the special cassette where small beads (white colour) are used for disruption of bacterial, viral and non-organic particles. Serial washes with appropriate buffers eliminate residues and nucleic acids (DNA and RNA) are then subjected for real-time PCR process. This process utilizes nested real-time PCR with use incorporation dye as an indicator.

Among Gastrointestinal Panel FilmArray offers detection of: V. cholerae, Shigella/Enteroinvasive E. coli (EIEC), Enteroaggregative E. coli (EAEC), Enteropathogenic E. coli (EPEC), Enterotoxigenic E. coli (ETEC), Shiga-like toxin-producing E. coli (STEC) stx 1/stx2 E. coli O157 with biothreat potency. The Biothreat screening kit includes: B. anthracis, F. tularensis, Y. pestis, Brucella spp. 


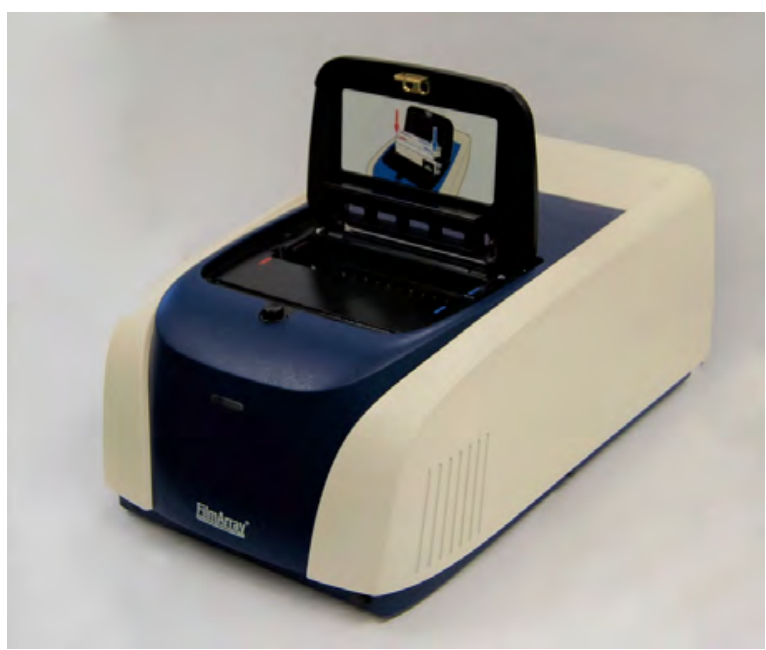

Figure 14. The FilmArray multiplex PCR system (BTICC)

Using this instrument it is possible to detect other biological agents described in following panels: Respiratory Panel (detection and identification of viruses: Adenovirus, Coronavirus HKU1, Coronavirus NL63, Coronavirus 229E, Coronavirus OC43, Human Metapneumovirus, Human Rhinovirus/ Enterovirus, Influenza A, Influenza A/H1, Influenza A/H3, Influenza A/H12009, Influenza B, Parainfluenza Virus 1, Parainfluenza Virus 2, Parainfluenza Virus 3, Parainfluenza Virus 4, Respiratory Syncytial Virus; bacteria: Bordetella pertussis, Chlamydophila pneumoniae, Mycoplasma pneumoniae); Blood Culture ID and Meningitis Encephalitis Panel. All of the mentioned panels are dedicated for clinical samples (www.biofiredx.com), nonetheless they can be used by mobile laboratory.

The system enable to detect and identify biological agents in field use. The application of BioFire's patented pouch system (integrated freeze-dried reagents in special cartridges) increase reliability DNA based results. That system is convenient for detection of the most common biothreats, and also in the case of clinical samples.

\section{LAMP-PCR (Tetracore)}

This method offers compact real-time PCR instrument for rapid and specific detection of several biological factors. The T-COR 8 thermocycler may be used in the field as well as in the laboratories (including mobile laboratories). The commercial sets are not dedicated for diagnostic purpose (system is dedicated only for research use). 
The system include sample - processing devices at the point of care 'collect-totest'. The multiplex identification of biothreat agents as: Bacillus anthracis - lethal factor (pXO1), Bacillus anthracis - capA (pXO2), Brucella spp., Yersinia pestis, Francisella tularensis, Burkholderia spp., Venezuelan Equine Encephalitis Virus (VEE), Ortopox virus, African Swine Fever Virus, Capripox, genes encoding of botulinum toxins, ricin, abrin and Stphylococcus aureus enterotoxins (SEB).

Field detection of biological agents is a highly rigorous and complex process in case of diagnostic purpose. It requires knowledge concerning biology of infectious agents, highly-skilled and trained sampling team (which may be consisted by different specialists: doctors, medical physicians, biologists, chemists etc), appropriate sampling protocols and equipment. Above mentioned methods and instruments may be used not only in military purpose but can also be adopted as a support for other public health service forces including police, fire departments, border guard etc.

\section{References}

AEP-66, NATO Handbook for Sampling and Identification of Biological, Chemical and Radiological agents (SIBCRA). Edition A, Version 1, Published by the NATO Standardization Agency (NSA).

Andreotti P.E., Ludwig V.L., Peruski A.H., Tuite J., Morse S.S., Peruski L.F. Jr., Immunoassay of infectious agents, Biotechniques Euro Edition 2003, no. 35.

Bartoszcze M., Metody wykrywania zagrożeń bronią biologiczna, Przegląd Epidemiologiczny 2003, no. 57.

BioFire DX Company, USA, http://www.biofiredx.com/.

Christensen D.R., Hartman L.J., Loveless B.M., Frye M.S., Shipley M.A., Bridge D.L., Kulesh D.A., Detection of biological threat agents by real-time PCR: comparison of assay performance on the RAPID, the LightCycler, and the Smart Cycler platforms, Clinical chemistry 2006, no. 52.

Dhama K., Karthik K., Chakraborty S., Tiwari R., Kapoor S., Kumar A., Thomas P., Loop-mediated isothermal amplification of DNA (LAMP): a new diagnostic tool lights the world of diagnosis of animal and human pathogens: a review, Pakistan journal of biological sciences: PJBS 2014, no. 17.

Didenko V.V., DNA Probes Using Fluorescence Resonance Energy Transfer (FRET): Designs and Applications, Biotechniques 2001, no. 31.

Drosten C., Göttig S., Schilling S., Asper M., Panning M., Schmitz H., Günther S., Rapid detection and quantification of RNA of Ebola and Marburg viruses, Lassa virus, Crimean-Congo haemorrhagic fever virus, Rift Valley fever virus, dengue virus, and yellow fever virus by real-time reverse transcription-PCR, Journal of clinical microbiology 2002, no. 40.

Erlich H.A., Polymerase chain reaction, Journal of clinical immunology 1989, no. 9.

Grant P.R., Garson J.A., Tedder R.S., Chan P.K., Tam J. S., Sung J.J., Detection of SARS coronavirus in plasma by real-time RT-PCR, New England Journal of Medicine 2003, no. 349. 
Humppi T., Haataja T., Mustalahti S., Mölsä M., Fykse E.M., Tjärnage T., Identification of biological warfare agents - recent progress and future trends, [in:] Norwegian Defence Research Establishment (FFI), FFI-rapport 2015/01530, Norway 2015.

Karsai A., Muller S., Platz S., Hauser M.T., Evaluation of a Homemade SYBR Green I Reaction Mixture for Real-Time PCR Quantification of Gene Expression, Biotechniques 2002, no. 32.

Kubista M., Andrade J.M., Bengtsson M., Forootan A., Jonák J., Lind K., Ståhlberg A., The real-time polymerase chain reaction, Molecular aspects of medicine 2006, no. 27.

Mirski T., Bartoszcze M., Bielawska-Drózd A., Cieślik P., Michalski A., Niemcewicz M., Kocik J., Chomiczewski K., Review of methods used for identification of threat agents in environmental protection and human health aspects, Annals of Agricultural and Environmental Medicine 2014, no. 2.

Murphy J., Bustin S.A., Reliability of real-time reverse-transcription PCR in clinical diagnostics: gold standard or substandard?, Expert review of molecular diagnostics 2009, no. 9.

Nagy A., Vitaskova E., Cernikowa L., Krivda V., Jirincova H., Sedlak K., Hornickova J., Havlickova M., Evaluation of TaqMan qPCR System Integrating Two Identically Labelled Hydrolysis Probes in Single Assay, Scientific Reports 2016, no. 7.

Navaro E., Serrano-Heras G., Castano M.J., Solera J., Real-time PCR detection chemistry, Clinica Chimica Acta 2015, no. 439.

Niedrig M., Kursteiner O., Herzog C., Sonnenberg K., Evaluation of an Indirect Immunofluorescence Assay for Detection of Immunoglobulin M (IgM) and IgG Antibodies against Yellow Fever Virus, Clinical and Vaccine Immunology 2008, no. 15.

Notomi T., Okayama H., Masubuchi H., Yonekawa T., Watanabe K., Amino N., Hase T., Loop-mediated isothermal amplification of DNA, Nucleic Acids Research 2000, no. 28.

Parida M., Sannarangaiah S., Dash P.K., Rao P.V.L., Morita K., Loop mediated isothermal amplification (LAMP): a new generation of innovative gene amplification technique; perspectives in clinical diagnosis of infectious diseases, Reviews in medical virology 2008, no. 18.

Peruski N.H., Peruski L.F. Jr., Immunological Methods for Detection and Identification of Infectious Disease and Biological Warfare Agents., Clin Vaccine Immunol. 2003, no. 10.

Pfaffl M.W., Quantification strategies in real-time polymerase chain reaction, Martin Filion, Hg., Quantitative real-time PCR in Applied Microbiology 2012.

Ponchel F., Toomes C., Bransfield K., Leong F.T., Douglas S.H., Field S.L., Bell S.M., Combaret V., Puisieux A., Mighell A.J., Robinson P.A., Inglehearn C.F., Isaacs J.D., Markham A.F., Real-time PCR based on SYBR-Green I fluorescence: An alternative to the TaqMan assay for a relative quantification of gene rearrangements, gene amplifications and micro gene deletions, BMC Biotechnology 2003, no. 3.

QiaGen Company, https://www.qiagen.com.

Robert E., Farnell Jr. PhD, RNA Methodologies ( $4^{\text {th }}$ ed.) Chapter 18, RT-PCR: A Science and an Art Form 2010, USA 2010.

Schochetman G., Ou C.Y., Jones W.K., Polymerase chain reaction, The Journal Of Infectious Diseases 1988, no. 158.

Skottman T., Piiparinen H., Hyytiäinen H., Myllys V., Skurnik M., Nikkari S., Simultaneous real-time PCR detection of Bacillus anthracis, Francisella tularensis and Yersinia pestis, European Journal of Clinical Microbiology \& Infectious Diseases 2007, no. 26. 
Stanley States, PhD 'Security and Emergency Planning for Water and Wastewater Utilities', American Water Works Association 2010.

Tetracore Inc., http://tetracore.com/elisa-kits/index.html.

Thremofisher Company, https://www.thermofisher.com/order/catalog/product/ 4368814, USA.

Tong Y., Tang W., Kim H.J., Pan X., Ranalli T., Kong H., Development of isothermal TaqMan assays for detection of biothreat organisms, Biotechniques 2008, no. 45.

Trombley A.R., Wachter L., Garrison J., Buckley-Beason V.A., Jahrling J., Hensley L.E., Kulesh D.A., Comprehensive panel of real-time taqman ${ }^{\mathrm{rax}}$ polymerase chain reaction assays for detection and absolute quantification of filoviruses, arenaviruses, and new world hantaviruses, The American journal of tropical medicine and hygiene 2010, no. 82.

Venkatesan G., Bhanuprakash V., Balamurugan V., Prabhu M., Pandey A.B., TaqMan hydrolysis probe based real time PCR for detection and quantitation of camelpox virus in skin scabs, Journal of Virological Methods 2012, no. 181.

Wilhelm J., Pingoud A., Real time polymerase chain reaction, Chembiochem 2003, no. 4.

http://bl-inc.jp/imno_e.html

http://www.abcam.com/secondary-antibodies/direct-vs-indirect-immunofluorescence http://www.biobest.co.uk/diagnostics/techniques/immunofluorescence-tests.html http://www.labgene.ch/real-time-pcr-kits/381-fast-track-diagnostics-real-time-pcr-kits.html

http://www.med.navy.mil/sites/nepmu2/Documents/lab/Hand\%20Held\%20Assays\%20(HHA).pdf 